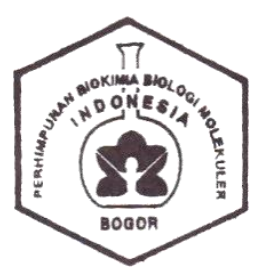

CURRENT BIOCHEMISTRY

ISSN: $2355-7877$

e-ISSN: $2355-7931$

Journal homepage: http://journal.ipb.ac.id/index.php/cbj

Journal E-mail: current.biochemistry@gmail.com

\title{
Antibacterial activity of Ethanol Extract of Spirulina platensis
}

(Aktivitas Antibakteri Ekstrak Etanol Spirulina platensis)

\author{
Prayoga Pannindriya ${ }^{1}$, Mega Safithri ${ }^{*}$, Kustiariyah Tarman ${ }^{2,3}$ \\ ${ }^{1}$ Department of Biochemistry, IPB University, Bogor, 16680, Indonesia \\ ${ }^{2}$ Department of Aquatic Product Technology, Faculty of Fisheries and Marine Science, IPB \\ Univeristy, 16680, Indonesia \\ ${ }^{3}$ Division of Marine Biotechnology, Center for Coastal and Marine Resources Study, IPB \\ University, 16680, Indonesia
}

Received:2 October 2020; Accepted: 2 December 2020

Corresponding author : Mega Safithri; Departemen Biokimia IPB; e-mail: safithri@apps.ipb.ac.id

\begin{abstract}
Spirulina is a microalgae that has been widely used as various supplements and medicines because of its high nutritional content. The need for new antibacterial sources to solve the problem of antibiotic resistance, makes the potential of Spirulina as an antibacterial agent necessary to be researched. This study aims to analyze the antibacterial activity of ethanol extract of Spirulina platensis obtained from the Indonesian region against Staphylococcus aureus and Escherichia coli. Spirulina samples were macerated in ethanol solvent in a ratio of 1:10 (w/v). The antibacterial activity test was performed using the disc diffusion method with clindamycin as a positive control. Results showed that the ethanol extract of $S$. platensis did not have antibacterial activity against $E$. coli and $S$. aureus. It was concluded that $S$. platensis has no potency to be used as a source of antibacterial agents against E. coli and S.aureus.
\end{abstract}

Keywords: Antibacterial, Escherichia coli, Spirulina platensis, Staphylococcus aureus

\begin{abstract}
ABSTRAK
Spirulina adalah mikroalga yang telah banyak digunakan untuk berbagai suplemen dan obat karena kandungan nutrisinya yang tinggi. Kebutuhan akan sumber antibakteri baru untuk mengatasi masalah resistensi antibiotik, membuat potensi spirulina sebagai agen antibakteri perlu untuk diteliti. Penelitian ini bertujuan untuk menganalisis aktivitas antibakteri ekstrak etanol Spirulina platensis yang diperoleh dari wilayah Indonesia terhadap Staphylococcus aureus dan Escherichia coli. Sampel Spirulina dimaserasi dalam pelarut etanol dengan perbandingan 1:10 (b/v). Uji antibakteri yang digunakan adalah metode difusi cakram dengan kontrol positif klindamisin. Hasil uji antibakteri menunjukkan bahwa ekstrak etanol S. platensis dalam penelitian ini tidak memiliki aktivitas antibakteri terhadap E. coli dan S. aureus. Disimpulkan bahwa spirulina tidak berpotensi untuk digunakan sebagai sumber bahan antibakteri terhadap E. coli dan S. aureus.
\end{abstract}

Keywords: Antibacteria, Escherichia coli, Spirulina platensis, Staphylococcus aureus 


\section{PENDAHULUAN}

Spirulina adalah mikroalga yang memiliki banyak peranan baik di bidang pangan maupun medis karena nilai nutrisinya seperti kandungan protein, vitamin, asam lemak esensial, dan mineralnya yang tinggi (Lupatini et al. 2016). Kandungan nutrisinya yang tinggi membuat spirulina dapat dijadikan sebagai bahan berbagai suplemen maupun obat untuk mengatasi penyakit. Salah satunya yang perlu diteliti lebih lanjut adalah potensinya sebagai agen antibakteri (Ozdemir et al 2004).

Potensi spirulina sebagai agen antibakteri penting untuk diteliti karena adanya kebutuhan akan agen antibakteri baru. Selama ini, antibiotik merupakan obat utama yang digunakan dalam mengatasi infeksi bakteri. Sayangnya, penggunaan antibiotik secara luas dari tahun ke tahun juga menimbulkan masalah yaitu munculnya resistensi bakteri terhadap antibiotik. (Pradipta et al 2012). Sumber agen antibakteri baru yang tidak berisiko menyebabkan resistensi sangat dibutuhkan saat ini.

Beberapa penelitian telah membuktikan potensi ekstrak spirulina sebagai antibakteri. Elshouny et al. (2017), menunjukkan bahwa ekstrak etanol Spirulina platensis secara in vitro memiliki aktivitas antibakteri yang baik terhadap beberapa jenis bakteri seperti Escherichia coli, Salmonella sp., Shigella sp., Staphylococcus aureus, dan Pseudomonas aeruginosa. Penelitian lain yang telah dilakukan oleh Nihal et al. (2018) menyatakan bahwa ekstrak air $S$. platensis juga memiliki aktivitas antibakteri terhadap Staphylococcus epidermidis dan Cutibacterium acnes. Oleh karena itu, penelitian ini bertujuan untuk menganalisis aktivitas antibakteri ekstrak etanol dari spirulina yang diperoleh dari wilayah Indonesia.

\section{METODOLOGI}

Bahan-bahan yang digunakan dalam penelitian ini adalah bubuk Spirulina platensis yang diperoleh dari Jepara, etanol 70\%, Escherichia coli, Staphylococcus aureus, kertas cakram, aluminum wrap, plastic wrap, Nurtrient Agar, Nutrient Broth, dan klindamisin.

Alat-alat yang digunakan adalah neraca analitik, inkubator goyang, pompa vakum, rotary evaporator, laminar air flow, cawan petri, pipet mikro jangka sorong, hotplate, inkubator, pinset, dan autoklaf.

\section{Tahapan Penelitian \\ Ekstraksi Spirulina}

Ekstraksi spirulina dilakukan menggunakan pelarut etanol 70\%. Sampel berwujud bubuk dimaserasi dengan perbandingan sampel:pelarut 1:10 (b/v). Maserat diinkubasi selama 24 jam menggunakan inkubator goyang pada suhu ruang dengan kecepatan $125 \mathrm{rpm}$. Maserasi diulangi hingga dihasilkan maserat dengan warna mendekati bening. Maserat disaring menggunakan kertas saring dengan bantuan pompa vakum. Filtrat yang diperoleh diuapkan pelarutnya menggunakan rotary evaporator pada suhu $50^{\circ} \mathrm{C}$ hingga terbentuk pasta kering. Rendemen ekstraksi dihitung menggunakan persamaan:

Rendemen $=\frac{\text { Bobot ekstrak }(\mathrm{g})}{\text { Bobot simplisia }(\mathrm{g})} \times 100 \%$

\section{Analisis Aktivitas Antibakteri}

Analisis aktivitas antibakteri dilakukan menggunakan metode difusi cakram berdasarkan Febriyani et al. (2018) dengan modifikasi. Bakteri uji yang digunakan adalah Escherichia coli dan Staphylococcus aureus. Ekstrak spirulina dilarutkan dalam akuades dengan konsentrasi 10.000 ppm. Bakteri uji diinokulasikan ke permukaan NA menggunakan mikro pipet. Kertas cakram yang sudah diberi larutan ekstrak spirulina, 
diletakkan di atas permukaan agar. Klindamisin 20 ppm digunakan sebagai kontrol positif dan akuades sebagai kontrol negatif. Setelah diaplikasikan, cawan petri dibalik dan diinkubasi pada suhu $35^{\circ} \mathrm{C}$ selama 1 malam. Zona hambat bakteri terbentuk sebagai daerah di sekeliling cakram yang tidak ditumbuhi bakteri. Diameter zona hambat diukur menggunakan jangka sorong. Percobaan dilakukan secara triplo.

\section{HASIL}

\section{Rendemen Ekstraksi Spirulina}

Ekstraksi simplisia Spirulina platensis dilakukan menggunakan pelarut etanol $70 \%$ dengan maserasi sebanyak 6 kali hingga warna maserat mendekati bening. Warna maserat yang memudar menunjukkan bahwa senyawa yang pada simplisia sudah teresktrak pada remaserasi sebelumnya. Proses ekstraksi spirulina menghasilkan rendemen sebesar $22.89 \%$.

\section{Aktivitas Antibakteri Ekstrak Spirulina}

Uji aktivitas antibakteri menujukkan bahwa cakram dengan ekstrak spirulina tidak memiliki zona hambat baik pada bakteri $E$. coli maupun $S$. aureus. Hasil tersebut menunjukkan bahawa ekstrak etanol spirulina tidak memiliki aktivitas antibakteri terhadap $E$. coli maupun $S$. aureus.

\section{PEMBAHASAN}

Ekstraksi spirulina menggunakan pelarut etanol menghasilkan rendemen sebesar $22.89 \%$. Penelitian sebelumnya oleh Mariyanti
(2017) dengan pelarut metanol 1:5 (b/v) dan 3 kali maserasi menunjukkan hasil yang lebih rendah yaitu $8.64 \%$.

Penelitian lain oleh Fajarwati (2017) menggunakan pelarut metanol 1:10 (b/v) juga dengan maserasi 3 kali menunjukkan hasil yang tidak jauh berbeda yaitu $8.66 \%$. Hal ini menunjukkan bahwa perbedaan nilai rendemen dapat disebabkan oleh perbedaan jumlah pengulangan maserasi dan pelarut yang digunakan. Banyaknya senyawa berbanding lurus dengan lamanya waktu ekstraksi. Perbandingan jumlah pelarut dengan ekstrak juga dapat memengaruhi nilai rendemen. Semakin banyak pelarut yang digunakan, semakin banyak senyawa yang dapat terekstrak. Jika pelarut terlalu sedikit, senyawa-senyawa dalam sampel tidak dapat terekstrak dengan sempurna. Tetapi jika pelarut terlalu banyak, akan memboroskan pelarut (Lapornik et al. 2005; Kurd dan Samavati 2015).

Uji antibakteri dengan metode difusi cakram menunjukkan bahwa ekstrak etanol Spirulina platensis tidak memiliki aktivitas antibakteri (Tabel 1). Hal ini terlihat dari tidak terbentuknya zona inhibisi di sekitar cakram yang diberi ekstrak etanol spirulina seperti terlihat pada Gambar 1. Hasil yang diperoleh berbeda dengan penelitian yang dilakukan oleh Elshouny et al. (2017) menggunakan spirulina kultur Universitas Tanta, Mesir di mana ekstrak etanol spirulina memiliki persentase inhibisi terhadap E. coli sebesar $91.07 \pm 5.1 \%$ dan S. aureus sebesar $90.7 \pm 7.0 \%$.

Tabel 1 Aktivitas antibakteri ekstrak etanol Spirulina platensis

\begin{tabular}{lcc}
\hline Bakteri & Sampel & Diameter zona hambat (mm) \\
\hline \multirow{3}{*}{ E. coli } & Ekstrak spirulina* & $0 \pm 0$ \\
& Klindamisin (kontrol positif) & 28.22 \\
& Aquadest (kontrol negatif) & 0 \\
S. aureus & Ekstrak spirulina* & $0 \pm 0$ \\
& Klindamisin (kontrol positif) & 30.50 \\
\hline
\end{tabular}

* Dilakukan 3 ulangan 
Berbedanya hasil yang diperoleh dapat disebabkan karena galur dan perlakuan spirulina yang digunakan sehingga komposisi bioaktif di dalamnya juga akan berbeda. Metode pemanenan dan modifikasi pasca panen hingga pemberian bahan tambahan juga dapat memengaruhi komposisi kimia dari spirulina (Aouir et al. 2017; Nouri dan Abbasi 2018; Mishra et al. 2008). Modifikasi spirulina dari pembiakan hingga menjadi produk komersial dapat menyebabkan hilangnya aktivitas antibakteri dalam sampel spirulina.

Perbedaan hasil tersebut dapat menyebabkan perubahan komposisi senyawa aktif antibakteri pada spirulina seperti asam $\gamma$ - linoleat, asam laurat dan asam palmitoleat (ElSheekh et al. 2014). Metode pengujian yang digunakan juga memengaruhi hasil, sebagai contoh penelitian Elshouny et al. (2017) menggunakan metode kuantitatif dengan microplate reader assay. Menurut Klančnik et al. (2010), tidak munculnya zona inhibisi pada pengujian aktivitas antibakteri ekstrak dengan metode difusi cakram belum tentu karena ekstrak yang diujikan tidak memiliki aktivitas antibakteri terutama senyawa non polar yang lambat berdifusi pada media. Senyawa aktif non polar akan sulit larut dalam air sehingga membuat senyawa tersebut sulit berdifusi.

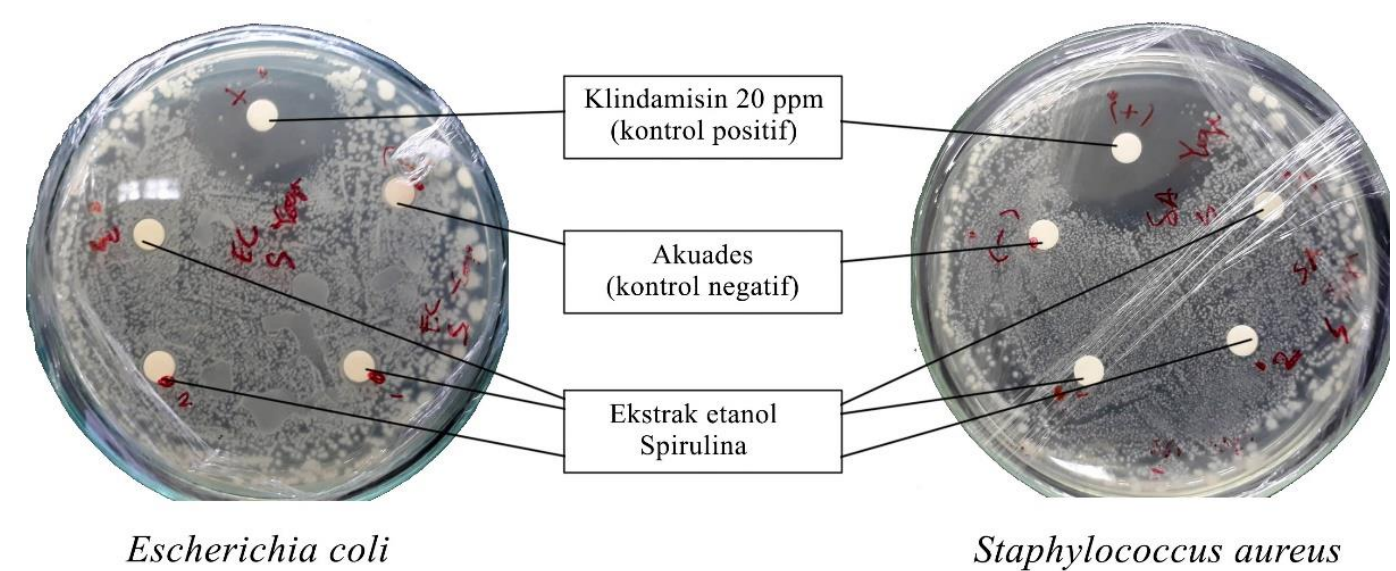

Gambar 1 Analisis aktivitas antibakteri ekstrak etanol Spirulina platensis

\section{UCAPAN TERIMA KASIH}

Ucapan terima kasih diberikan kepada Departemen Biokimia Institut Pertanian Bogor yang telah menyediakan tempat dan fasilitas untuk dilaksanakannya penelitian ini.

\section{DAFTAR PUSTAKA}

Aouir A, Amiali M, Bitam A, Benchabane A, Raghavan VG. 2017. Comparison of the biochemical composition of different Arthrospira platensis strains from Algeria, Chad and the USA. Journal of Food Measurement and Characterization. 11(2): 913-923

El-Sheekh MM, Daboor SM, Swelim MA, Mohamed S. 2014. Production and characterization of antimicrobial active substance from Spirulina platensis. Iranian Journal of Microbiology. 6(2): 112-119

Elshouny WAE, El-Sheekh MM, Sabae SZ, Khalil MA, Badr HM. 2017. Antimicrobial activity of Spirulina platensis against aquatic bacterial isolates. Journal of Microbiology, Biotechnology, \& Food Sciences. 6(5): 1203-1208

Fajarwati Y. 2017. Aktivitas penghambatan malondialdehida (MDA) secara in vitro dan toksisitas ekstrak metanol Stichopus hermanii dan Spirulina platensis. [skripsi]. Bogor (ID): Institut Pertanian Bogor 
Klančnik A, Piskernik S, Jeršek B, Možina SS. 2010. Evaluation of diffusion and dilution methods to determine the antibacterial activity of plant extracts. Journal of Microbiological Methods. 81(2): 121-126

Kurd F, Samavati V. 2015. Water soluble polysaccharides from Spirulina platensis: Extraction and in vitro anticancer activity. International Journal of Biological Macromolecules. 74: 498506

Lapornik B, Prošek M, Golc Wondra A. 2005. Comparison of extracts prepared from plant by-products using different solvents and extraction time. Journal of Food Engineering. 71(2): 214-222

Lupatini AL, Colla LM, Canan C, Colla E. 2016. Potential application of microalgae Spirulina platensisas a protein source. Journal of the Science of Food and Agriculture. 97(3): 724-732.

Madigan MT, Bender KS, Buckley DH, Sattley WM, Stahl DA. 2019. Brock Biology of Microorganisms $15^{\text {th }}$ Edition. New York (US): Pearson.

Mariyanti S. 2017. Kandungan kimia dan aktivitas penghambatan AlfaGlukosidase secara in vitro dari ekstrak metanol Stichopus hermanii dan Spirulina platensis. [skripsi]. Bogor (ID): Institut Pertanian Bogor

Mishra SK, Shrivastav A, Mishra S. 2008. Effect of preservatives for food grade CPC from Spirulina platensis. Process Biochemistry, 43(4): 339-345

Nihal B, Gupta NV, Gowda DV, Manohar M. 2018. Formulation and development of topical anti acne formulation of Spirulina extract. International Journal Applied Pharmaceutics. 10(6): 229-233

Nouri E, Abbasi H. 2018. Effects of different processing methods on phytochemical compounds and antioxidant activity of Spirulina platensis. Applied Food Biotechnology. 5(4): 221-232
Ozdemir G, Karabay NU, Dalay MC, Pazarbasi B. 2004. Antibacterial activity of volatile component and various extracts of Spirulina platensis. Phytotherapy Research. 18(9): 754-757

Pradipta IS, Febrina E, Ridwan MH, Ratnawati R. 2012. Identifikasi pola penggunaan antibiotik sebagai upaya pengendalian resistensi antibiotik. Jurnal Farmasi Klinik Indonesia. 1(1): 16-24 